\title{
ROMAN SURGICAL AND MEDICAL INSTRUMENTS FROM LA CAÑADA HONDA (GANDUL)*
}

\author{
POR \\ VIVIAN A. HIBBS \\ The Hispanic Society of America, New York, USA
}

\begin{abstract}
RESUMEN
Este artículo presenta el catálogo de un conjunto significativo de instrumentos romanos médico-quirúrgicos procedentes de la necrópolis de La Cañada Honda (Gandul, Sevilla) excavada por Jorge E. Bonsor entre 1908 y 1910 y que se conservan ahora en la Hispanic Society of America. La variedad de tipos de instrumentos es un indicio de que se practicó una medicina adecuada en la zona durante la segunda mitad del siglo I y primera mitad del siglo II de nuestra era.
\end{abstract}

\section{SUMMARY}

This article presents a catalogue of a significant group of Roman medical/surgical instruments discovered in a necropolis of incineration burials at La Cañada (Gandul, Sevilla) excavated by George E. Bonsor between 1908 and 1910 and now in the collections of the Hispanic Society of America. The variety of types of instruments indicates the existence of an adequate medical profession in the area during the second half of the first century and first half of the second century A.D.

Medicine played an important role in classical antiquity as attested to by the ancient physicians, such as Hippocrates, Galen and Celsus, who in their writings give detailed descriptions of medical practices, including treatment, surgical procedures and medications ${ }^{1}$. These ancient sources have been augmented by the actual Roman medical and surgical instruments

* All photographs are courtesy of the Hispanic Society of America.

1 John Scarborough, Roman Medicine, Ithaca, N.Y., 1976, 149-167, gives biographical sketches of physicians and authors as well as a bibliography of ancient sources. 
which have been discovered in excavations of tombs, houses of surgeons, public buildings (i.e., amphitheaters and theaters), and military hospitals. Nevertheless, a subject which would appear to fascinate many has in fact motivated but only relatively few scholars, - in Spain and elsewhere-, to undertake intensive investigations of the material, a phenomenon which is perhaps due to its scientific nature ${ }^{2}$.

While researching Roman medical instruments in preparation for an exhibition of a group of these implements from Spain at the museum of the Hispanic Society of America, an increased interest in the subject during the last decade was noted. In addition to Ernst Künzl's corpus of medical instruments discovered in Roman tombs throughout the Roman Empire, which are considered in relation to other furnishings in these tombs and the type of burial ${ }^{3}$, several articles dealing with Roman medical instruments from Roman sites in Spain have appeared ${ }^{4}$. One of these authors drew attention to the paucity of publications on this material and the general lack of references to ancient medical activity in the Spanish archaelogical literature and the need for a corpus of surgical and medical instruments from Roman Spain ${ }^{5}$. In 1988 this task was indeed accomplished with the publication of Enrique Luis Borobia Melendo's comprehensive study of Roman medical, surgical and pharmaceutical instruments discovered in the Iberian Peninsula. The material, gathered from both private and public collections, is organized by region, provenance and present location. Following Milne's approach, each type of instrument and its use is described and interpreted on the basis of the classical texts, many of which are included, and his own personal medical experience ${ }^{6}$.

In the light of the above, the purpose of this article is to present a group of seventy-one Ro-

2 John St. Milne, Surgical Instruments in Greek and Roman Times, Oxford, 1907. Reprint, New York, 1970. Milne's classification of the instruments based on ancient texts as well as comparative material has remained basic for all future studies; Th. Meyer Steineg, Chirurgische Instruments aus dem Altertum. Ein Beitrag zur antiken Akiurgie, 1912 (instruments from Kos and Ephesos); M. Iñiguez Ortiz, Numancia y la medicina en la antigua Iberia, Zaragoza, 1916; Antonio C. Floriano, «Aportaciones arqueológicas a la historia de la medicina romana", Archivo Español de Arqueología, 14, 1940-1, 415433; J. A. Sáenz de Buruaga y J. García de Soto, «Nuevas aportaciones al estudio de la necrópolis oriental de Mérida", Archivo Español de Arqueología, 19, 1946, 70-85; M. Tabanelli, Lo strumento chirurgico e la sua storia, 1958 (instruments from Pompeii); J. R. Zaragoza Rubira, Medicina y sociedad en la España romana, Barcelona, 1971, 105-111.

3 Ernst Künzl, «Medizinische Instruments aus Sepulkralfunden der romischen Kaiserzeit», Bonner Jahrbucher, 182, 1982, I-132. An excellent well-organized and well-illustrated study. From the Iberian Peninsula, only Belo in Baetica (Andalucía), Balsa/Torre de Area (Algarve, Portugal); three tombs at Mérida, one at Toledo and one at Paredes de Nava, Palencia, are included.

4 Montserrat Molina, «Instrumental médico de época romana en el Museo Arqueológico Nacional (Madrid)", Archivo Español de Arqueología, 54, 1981, 255-262, deals with collections from Belo and Palencia; Angel Fuentes Domínguez, «Instrumentos romanos de medicina en el Museo de Cuenca», $A r$ chivo Español de Arqueología, 60, 1987, 251-274.

5 Fuentes Domínguez, op. cit., n. 4, 251.

6 Enrique Luis Borobia Melendo, Instrumental médico-quirúrgico en la Hispania romana, Madrid, 1988. Borobia, a surgeon and professor of medicine as well as an amateur archeologist, has devoted much time to the study of ancient medicine and instruments. In this exhaustive study he has catalogued and discusses 408 objects from twenty-three locations and a group with unknown provenance, all of which are illustrated. Disconcerting are the pieces which are illustrated, but not mentioned in the text. 
man medical and surgical instruments in the collection of the Hispanic Society of America to add to the accumulated evidence for the magnitude and scope of the medical profession in Roman Spain.

All of the pieces were excavated by George E. Bonsor from a Roman necropolis of incineration burials at La Cañada Honda (Gandul) ${ }^{7}$, believed to be the burial grounds for Mesa de Gandul. Beginning excavations in 1908, Bonsor had opened 179 incineration burials at this site by October, $1910^{8}$. He described and drew the plans of what he considered the six principal tombs (nos. 3, 13, 57, 125, 140 and 162) including the location of the funerary offerings. In three of these a single instrument was found: in tomb 3, a bronze stylus; in tomb 140, a bronze «hollow» spatula and a tablet of black stone; and in tomb 162, a bronze cylindrical instrument case.

Künzl asserts that isolated finds such as these cannot be interpreted as medical instruments and that to be so qualified they must be found in association with surgical instruments ${ }^{9}$. However, while tweezers, probes, spatulas, round needles and styli were domestic utensils and used chiefly for hygienic and cosmetic purposes as well as by artisans, they were also a part of the physician's regular equipment, as evidenced by their inclusion in finds known to be medi$\mathrm{cal} /$ surgical. In addition to their use in various medical and surgical procedures, they were also used for pharmaceutical preparations, a task which in antiquity frequently fell to the physician himself. Thus, since information on the excavations at La Cañada Honda is limited, and since the number of instruments is impressive and genuine surgical pieces appear among them, it seems appropriate to present a catalogue of all of the items, subscribing to Borobia's contention that instruments concerned with personal hygiene are related to health care and should be considered as medical ${ }^{10}$.

The collection includes needles, scalpel and needle handles, probes, tweezers, spoons, shears, a possible bone lever, chisel, small slate tablets for grinding and mixing medications, instrument cases and medicament receptacles. As was usual in antiquity many of the instruments combine two implements in one.

Of the thirteen needles in the collection, seven are round eyed needles (fig. 1). These are long rods, circular in section, having a point ranging from blunt to sharp on one end and perforated on the opposite end. Their similarity to the domestic sewing needle is such that they

7 Situated to the north of Mesa de Gandul on the chain of hills of the Alcores $21 \mathrm{~km}$. southwest of Carmona and $22 \mathrm{~km}$. east of Seville. See George E. Bonsor, «La véritable origine de Carmona et les découverts archéologiques des Alcores», Revue Archéologique, 1927, 297. The necropolis consisted of incineration burials, dated by archaelogical evidence to the first century A.D., and later inhumation burials of the Roman, Christian and Visigothic periods, dated to the III/IV A.D. and later, all excavated but unpublished by Bonsor. It is associated with Mesa de Gandul, a site which due to its extensive area, profusion of marble remains including architectural fragments, and its location on a primary road testifies to a prosperous town. The material from both areas of the necropolis attest to a period of Roman activity from the beginning of Romanization to the end of the Empire (Fernando Amores Carredano, Carta arqueológica de Los Alcores (Sevilla), Seville, 1982, 126-129).

${ }^{8}$ Private correspondence in the collections of the Hispanic Society of America.

${ }^{9} \mathrm{Künzl}$, op. cit., n. 3, 6, considers the following as surgical: scalpel, knife, lance, forcep, retractor, lever, hook, saw, file, chisel, trepane, cupping glass, speculum, cauterizer, needle, catheter.

${ }^{10}$ Borobia, op. cit., n. 6, 326. 
can be classified as medical only in the sense that they were used for sewing bandages ", a practice which both Hippocrates and Celsus recommended ${ }^{12}$. The round needle was totally unsuitable for the suturing of human tissues, a procedure which would require a three-sided needle with sharp cutting edges and point ${ }^{13}$. Although these are frequently mentioned by ancient writers, no description of them has been noted. Milne proposes that they varied in size.

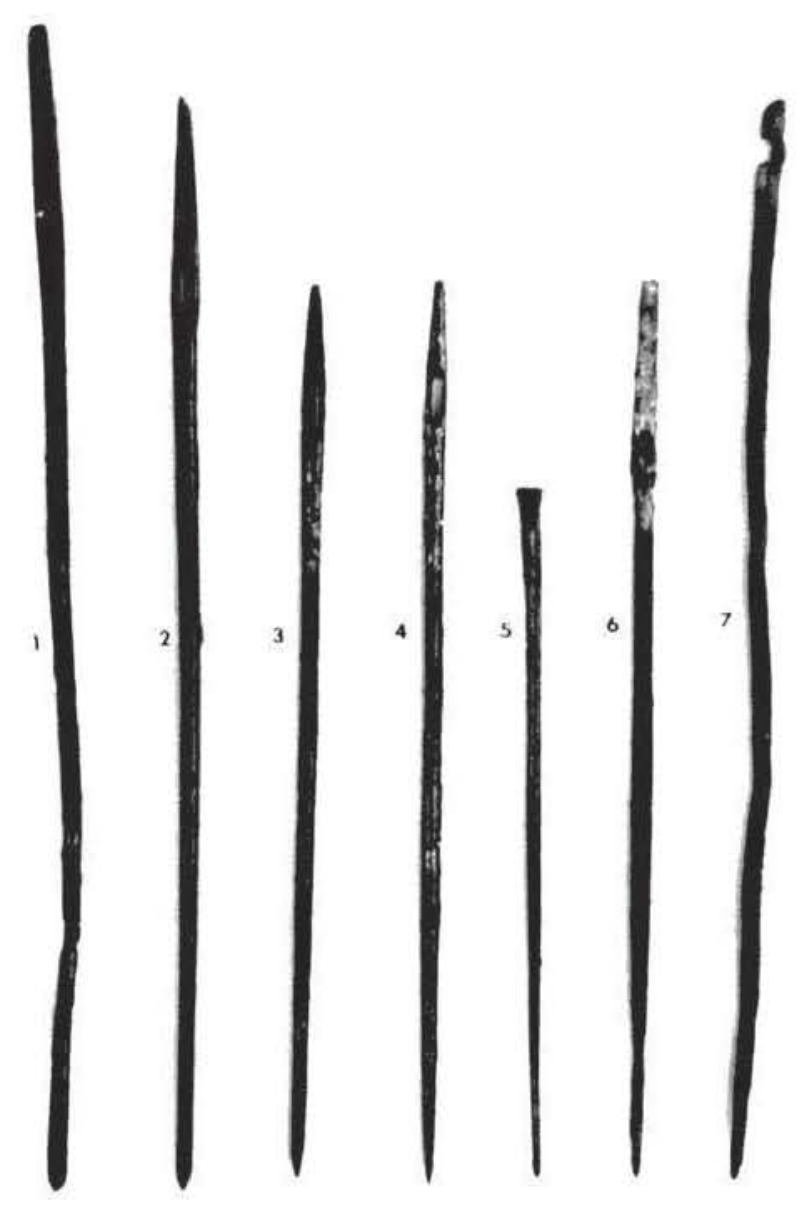

Figura 1.-Needles with eyes from La Cañada Honda (Gandul).

11 Milne, op. cit., n. 2, 75-76.

12 Hippocrates, In the Surgery, VIII, 11-14; Celsus, De Medicina, V, 26, 24-C. The latter, in describing the method of applying a bandage to a wound, states: «tum extrema pars eius inferioribus acu adsuenda est: nam nodus ulcus ladit, nisi tamen long est» («finally, the end of the bandage is to be stitched by means of a needle to the deeper turns; for a knot hurts the wound, unless, indeed, it is at a distance from it». [W. G. Spencer, Celsus, De Medicina, Loeb Classical Library, Cambridge, MA, 1939, II, 89]).

${ }_{13}$ Celsus, De Medicina, V, 26, 24-C, mentions the treatment of external wounds either by suture or by some sort of medication: «Nam plaga ipsa curanda extrinsecus vel sutura vel alio medicinae genere est"; also he asserts that a wound in soft flesh should be stitched, V, 26, 23 A-B: «Nam si plaga in molli parte est, sui debet, maximeque si discissa auris ima est vel imus nasus vel frons vel bucca vel palpebra vel labrum vel circa guttur cutis vel venter» 
however, according to the various procedures cited. Their rarity among archaclogical finds suggests that they were made of iron or steel ${ }^{14}$.

The five remaining eyeless needles (fig. 2, I (with rivet holes)-5) are trapezoidal tapering to a relatively sharp point. These were used for piercing and cauterizing. and consequently, in addition to the cautery and catarct needle. would have been useful to the oculist in the treatment of opthalmic conditions ${ }^{15}$. The cataract needle, according to Celsus, should be sharp and not too thin, a description which corresponds to a handled needle from Pompeii and one from Achaia ${ }^{16}$. Perhaps the fine example of a needle handle in the Society's collection carried a cataract needle, now missing except for the end remaining in the base (fig. 2, 7) 17 .

I know of no references to double needles in the ancient sources and they are comparatively rare among archaelogical finds. An example from Asia Minor has a molded spindle type
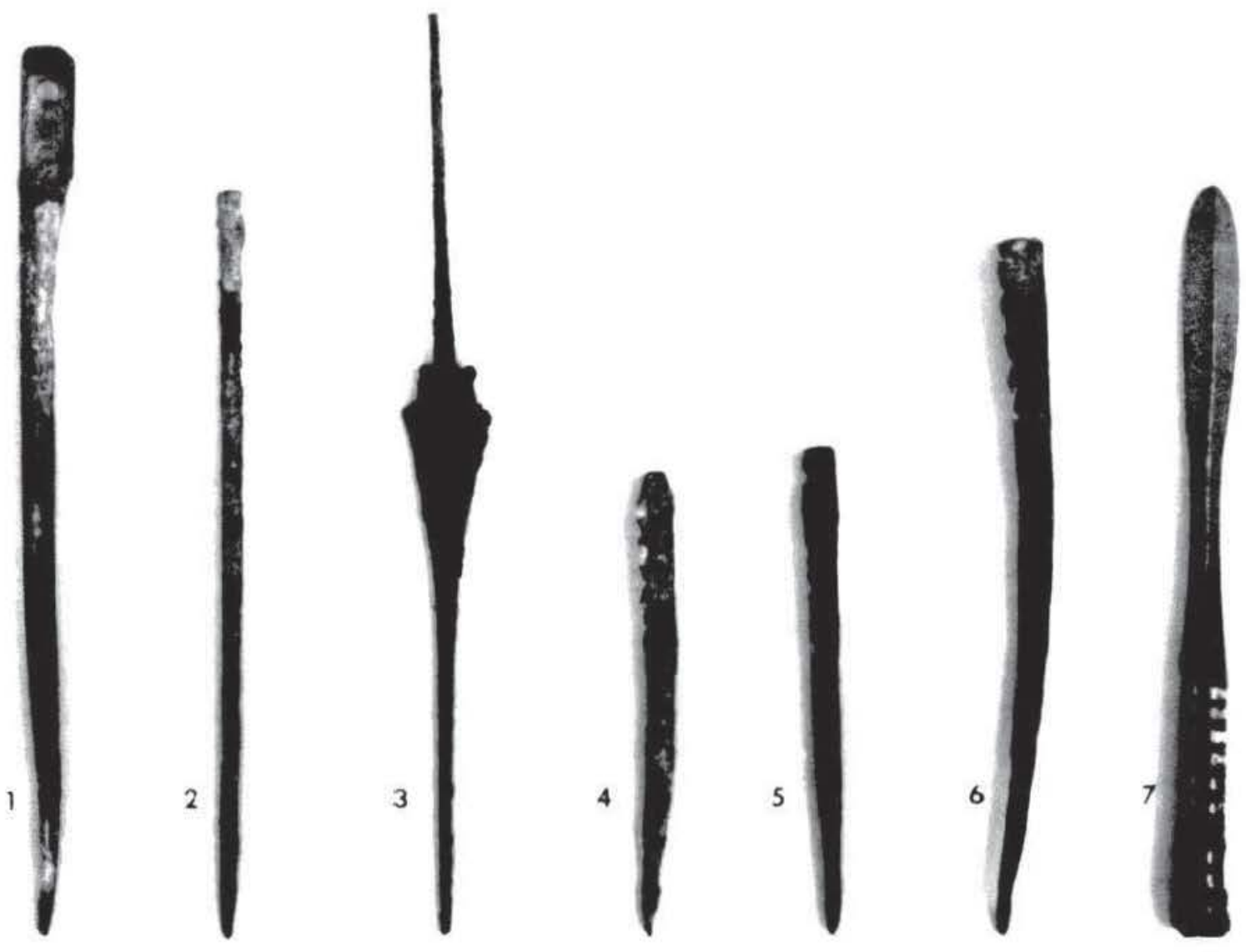

Figura 2.- Needles without eyes from La Cañada Honda (Gandul).

14 Milne, op. cit., n. 2, 74-75.

15 Künzl, op, cit., n. 3, 26-27; Milne, op. cit., n. 2, 69.

16 Celsus, De Medicina, VII, 7. 14-D: “Tum acus admovenda est, sic acuta, ut foret, non nimium tenuis»; Künzl, op. cil., n. 3, 14, fig. 4, 5 (Pompeii) and 43, fig. 10, 4 (Achaia).

17 Compare Lawrence J. Bliquez. "Greek and Roman Medicine», Archaeology, 34, 1981, 17, left. 7 th from top. 
grip ${ }^{18}$, but more unusual (fig. 2,3 ) is the example from La Cañada Honda which has a small triangular grip virtually identical to one from Morlungo (Italy), dated to the late first century A.D. ${ }^{19}$. Another, from Palencia, has a rectangular grip and is inscribed with the legend IIIXIII on both faces ${ }^{20}$.

The scalpel combined two instruments in one. It was composed of a bronze handle either cylindrical, rectangular, hexagonal or trapezoidal in section, in which a slot in one end received a steel or iron blade ${ }^{21}$, and the other end carried a bronze leaf-shaped spatula ${ }^{22}$. The spatula not only provided a firmer grip and less danger of injury when making deep incisions ${ }^{23}$, but it was also used for dissecting tumors and abscesses, and for various practical applications during surgical procedures ${ }^{24}$. Of the five scalpel handles in the collection one is pyriform (fig. 3, 1), three octagonal (fig. 3, 3-5), and one rectangular (fig. 3, 2) in cross-section. The latter shape is common throughout the Empire from the first through the third century A.D. and is the most prevalent in Spain ${ }^{25}$. One of the rarer octagonal examples is almost identical with one from Ercávica in size and shape ${ }^{26}$. Sufficient steel or iron blades or fragments thereof have survived in handles, as in R4365 (fig. 3, 2), to inform of their size and shape ${ }^{27}$. The pyriform handle (fig. 3,1 ) as well as the needle handle (fig. 2, 7), both bearing damascened ornamentation, are noteworthy since damascened handles occurred primarily in the third century although some first century examples have been noted ${ }^{28}$. Milne mentions a rare round type with a spiral silver inlay in the museum at Le Puy-en-Velay, also included in Künzl's corpus and dated to the late third century ${ }^{29}$, which is quite similar to that from La Cañada Honda (fig. 3, 1), but the latter has a tighter silver spiral and more molded rings at both ends of the pyriform.

I8 Künzl, op. cit, n. 3, 47 and 49, fig. 15, 10.

19 Künzl, op. cit., n. 3, 107, fig. 84 (assumption based on illustration).

20 Molina, op. cit., n. 4, 258.

21 On the slotted end either a groove is incised $1 \mathrm{~mm}$. from the end or the end is raised into a cylindrical roll on the two faces in order to fix the blades into the handle with a thread or wire, thereby permitting the removal and exchange of blades - a theory generally accepted. Milne, however, argues that blades were permanently attached to the handle (Milne, op. cit., n. 2, 24).

22 In general, Spanish scholars have mistaken the scalpel handle for the scalpel itself. This misconception has also been referred to by Borobia, op. cit., n. 6, 316-317.

${ }^{23}$ Künzl, op. cit., n. 3, 15.

${ }^{24}$ Celsus, de Medicina, VII, 6, 4, mentions using the handle of the scalpel for separating a sebaceous cyst from the skin and underlying flesh: «Protinus autem ut alba et intenta se ostendit, tum scalpelli manubriolo deducenda a cute et carne est, eiciendaque cum eo, quod intus tenet», VII, 7, 3: «deinde scalpelli manubriolo deducenda ab integris partibus sunt».

25 Borobia, op. cit., n. 6, 110-111, pl. 6, 2 (Palencia); 117-118, pl. 9, 1 (Toledo); 170-71, pl. 41, 1416 (Alcolea del Río); 177-178, pl. 42, 6-7 (Carmona); 186-88, pls. 70, 1-3, 56, 2 (Andalucía); 241-2, pl. 96, 2 and 245-6, pls. 84, 3, 5 (Mérida); pl. LXXXII, 1 and 265, pl. 103, 10-11 (Numancia); 300 pl. $112,5,15,13$, a 26 (Prov. unk.).

26 Borobia, op. cit., n. 6, pl. 15, 1; Fuentes Domínguez, op. cit., n. 4, 253, fig. 1, 1 - L. 86 cm.; L. of blade $3.75 \mathrm{~cm}$.; W. $0.9 \mathrm{~cm}$.; W. of handle $0.6 \mathrm{~cm}$.

27 Künzl, op. cit., n. 3, 15.

28 Milne, op. cit., n. 2, 25.

29 Künzl, op. cit., n. 3, 60, fig. 26, 1; Milne, op. cit., n. 2, 25, pl. II, 6. 
Probes form the largest group in the collection, consisting of six spoon probes (cyathiscomele) and seven fragments thereof (fig. 4, 1-13), a spatula probe (spathomele) (fig. 4, 14), and seven ear probes (auriscalpium or oricularium specillum) (fig. 5); the first two types having an olivary enlargement at one end which was used as a sound or probe to explore a wound or fistula; to apply medicaments or ointments to afflicted areas; to cauterize affected areas after removal of cysts; and to apply wool dipped in warm oil to relieve toothache ${ }^{30}$.

The spatula of the spathomele was used for mixing and spreading medications, for blunt dissection and as a tongue depressor ${ }^{31}$. In the cyathiscomele the spatula is angled longitudinally to form a spoon ${ }^{32}$, thus being better adapted to mixing, measuring and applying liquid medications. Both types, however, were also used for the preparation of cosmetics and colors by artists and artisans ${ }^{33}$.

The ear probe (fig. 5) consists of a circular rod pointed on one extremity with a round disc, either flat or concave, at the opposite end set at an angle to the axis of the rod ${ }^{34}$. Occasionally the rod has an olivary rather than a pointed end as in R4336 (fig. 5, 1). Basically dedicated to aural work, i.e., removing small foreign objects from the ear and instilling liquids into it ${ }^{35}$, it was also valuable in delicate surgical procedures requiring small fine instruments. The pointed tip was used to perforate flesh and for probing wounds and fistulae. Heated, it was used as a cautery ${ }^{36}$. Ear probes, tweezers and styli are sometimes found attached to a metal ring, perhaps the property of a private individual, thus falling into the category of personal hygiene. One pair of tweezers (R4261) in the collection is perforated at the top for this purpose (fig. 6, 9).

Serving as household, cosmetic and surgical implements, tweezers are most frequently encountered among ancient instruments. Those in the Society's collection are of the type commonly used for epilation ${ }^{37}$. While removal of facial hair with tweezers or forceps and knife for cosmetic purposes dates back to the prehistoric period, in the Greek and Roman period shaving was the normal procedure and a tweezers was used primarily for removal of super-

${ }^{30}$ Celsus, De Medicina, V, 28, 12-C: «Ante omnia autem demitti specillum in fistulam convenit, ut quo tendat at quam alte perveniat...» VI, 9, 3: «Specillum quoque lana involutum in calidum oleum demittitur, eoque ipse dens fovetur».

31 Bliquez, op. cit., n. 17, 13; Milne, op. cit., n. 2, 58-59.

32 Milne, op. cit., n. 2, 61-62.

33 Donald Strong and David Brown, eds., Roman Crafts, London, 1976, 220, cites two spatula probes discovered among the apparatus of a painter at St. Médard-des-Pres.

34 This type, which is referred to in general as an ear probe, Milne identifies as ligula specillum for use in removing medicaments from jars, etc. (Milne, op. cit., n. 2, 77-78). He describes the oricularium specillum as a circular rod with a small narrow scoop similar to the spoon of the cyathiscomele on one end and pointed on the other (Milne, ibid., 63-64). Bliquez follows Milne, but notes the ambivalent character of these instruments (L. J. Bliquez, «Roman Surgical Instruments in the Johns Hopkins University Institute of the History of Medicine», Bulletin of the History of Medicine, 56, 1982, 206-207). See also Fuentes Domínguez, op. cit., n. 4, 254, no. 4 and 264.

35 Milne, op. cit., n. 2, 67. Liquid was instilled into the ear by winding wool saturated with medication around the center of the rod from which, when squeezed, the liquid flowed off the end.

36 Milne, op. cit., n. 2, 63-68.

37 Künzl, op. cit., n. 3, 18. 


$$
11111
$$




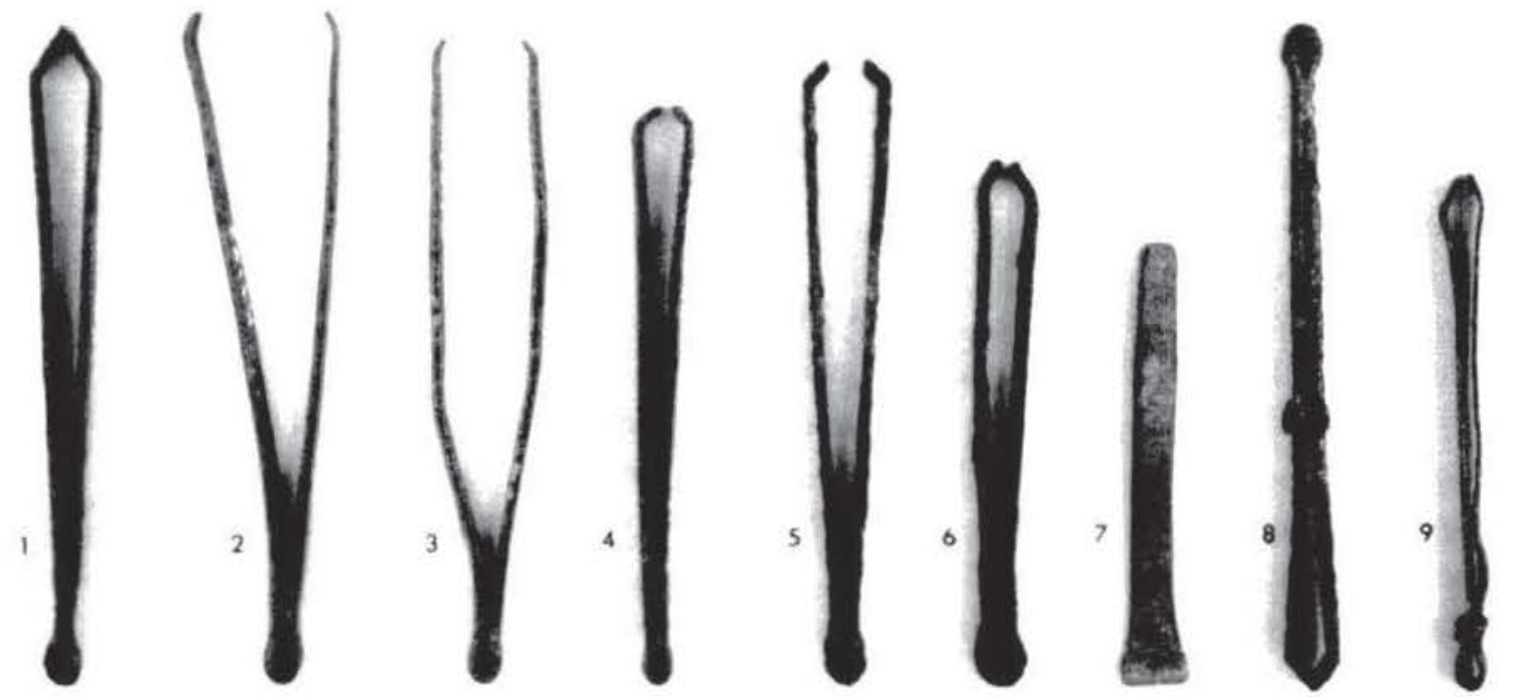

Figura 5.- Ear probes from La Cañada Honda (Ciandul).
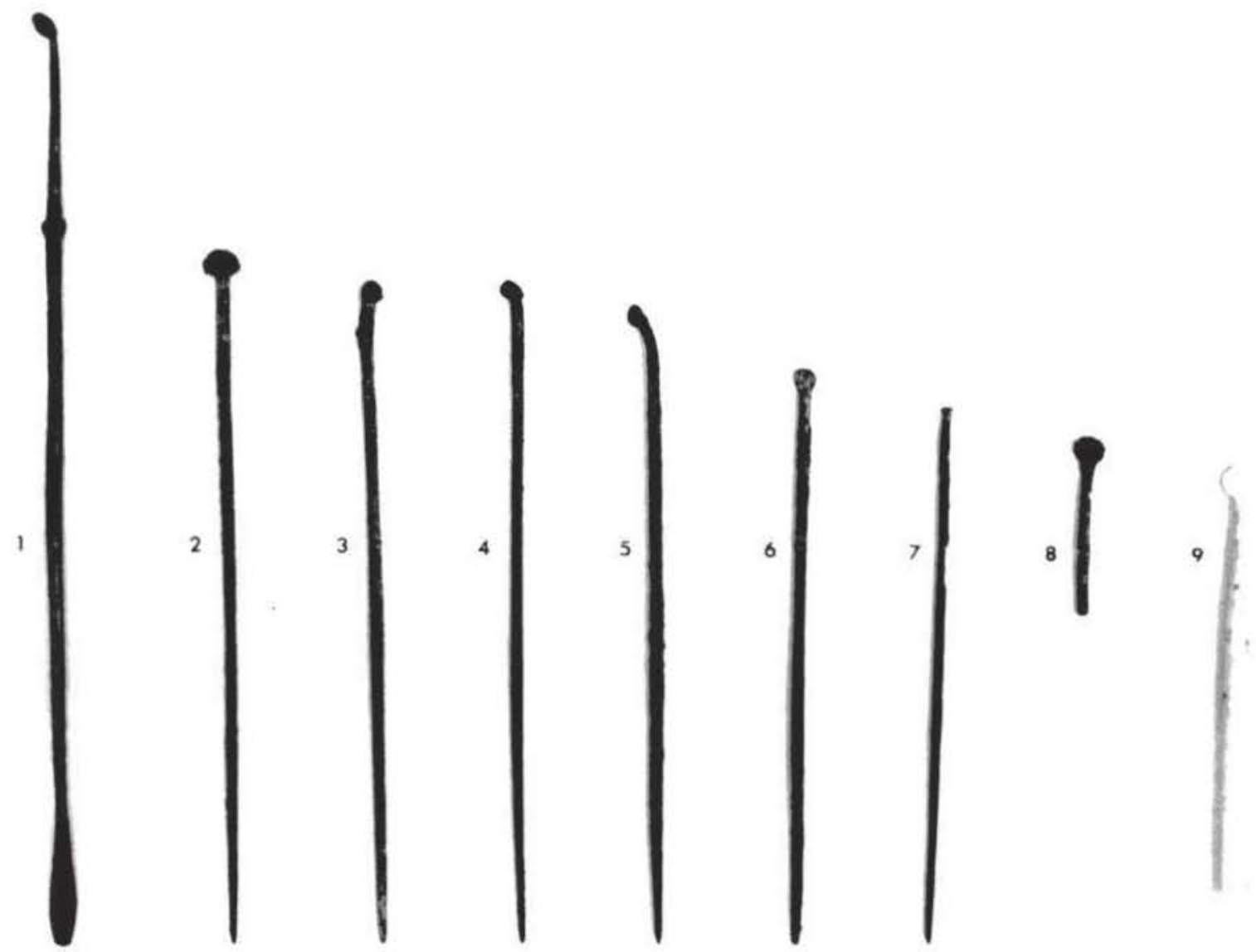

Figura 6.-Tweezers from La Cañada Honda (Gandul). 
fluous hairs ${ }^{3 x}$. Nevertheless, they are often found among surgical finds. Paul of Aegina mentions their use in removing hairs from the inner eyelid in the disease of trichiasis after which the area is cauterized with an olivary or ear probe ${ }^{39}$. Other functions include extraction of teeth, and of bone splinters, arrows or other foreign objects from wounds ${ }^{40}$.

Other than the nine examples in our collection, are thirty-five illustrated by Borobia from Ampurias, Palencia, several sites in Andalucía, and of unknown provenance ${ }^{41}$. Sliding adjustors on some provided a better grip on hair to be removed, but also could serve as a clamp during surgical procedures to prevent injury to nerves, veins and arteries ${ }^{42}$. Two examples in our collection are provided with such adjustors (fig. 6, 8-9).

Of the three examples of round spoons from La Cañada Honda (fig. 7, 1-3), one fully preserves the spoon on a long pointed cylindrical rod. With such spoons medications were measured, administered and heated, the latter action often resulting in deterioration of the bottom of the spoon as in R4379 (fig. 7, 2).

Shears, which have survived in both iron and bronze, are relatively rare among archaelogical finds ${ }^{43}$. Ranging in size from 6.0 to $19.8 \mathrm{~cm}$., Borobia has pointed out that the smaller specimens would more probably relate to the medical sphere ${ }^{44}$. The two principal types, both reflecting a Hellenistic model, function through the spring action of the metal. The Society's example (fig. 7,4 ) as well as two from Mérida, two from the province of Soria, one from Numancia, and one from Naples, have the simple hairpin-shaped handle ${ }^{45}$, while in the examples from Palencia and one from the province of Soria, a ring at the apex provided greater durability and resilience ${ }^{46}$. As to their use, we learn from both Oribasius and Celsus that cutting and shaving hair to the scalp was a therapeutic measure in the treatment of epilepsy and malarial

38 Milne, op. cit., n. 2, 90.

39 Paul of Aegina, VI, 14: «The eyelid is turned outward and with the depilatory tweezers, we pull out the offending hairs, one, two, three or as many as necessary. Immediately we apply a hot olivary or ear probe or any of the fine instruments on the place where the hairs which have been eliminated grew".

40 Milne, op. cit., n. 2, 90-93; Paul of Aegina, VI, 24; Celsus, De Medicina, VII, 5, 4-A: «In omnibus his latius vulnus aperiundum, idque quod inest, ea, qua venit, forfice estrahendum est»; VII, 12 B-C: «Ac si excessus est, ante [id foramen] vel linamento vel bene adcommodato plumbo replendus est, ne sub forfice confringatur. Recta vero forfex ducenda est, ne inflexis radicibus os rarum, cui dens inhaeret, parte aliqua frangat... Ergo specillo conquirenda est testa, quae recessit, et volsella protrahenda est».

${ }_{41}$ Borobia, op. cit., n. 6, Ampurias, pl. 3, 5-6, pl. 33, 1 and 3; Palencia, pl. 8, 1-4, 6-7; Andalucía, pl. 54, 1-4 pl. 62, 3, pl. 66, 1-2, 4-6; prov. unk., pl. 107, 13, pl. 109, 10-15, pl. 110, 10-18. See also Los bronces romanos, exhib. cat., Palacio de Velázquez, Madrid, May 30-July 31, 1990, 305-306, nos. 269. 271.

42 Borobia, op cit., n. 6, 50.

43 Künzl, op. cit., 20.

44 Borobia, op. cit., n. 6, 112.

45 Mérida: Borobia, op. cit., n. 6, 240, pl. 85, 8 (bronze), 246, pl. 90, 7 (iron). Prov. of Soria: Borobia, ibid., 286, pl. 77 (iron), 288, pl. 76, 5 (bronze). Numancia: Borobia, ibid., 270, pl. 99, 2 (iron). Naples: Milne, op. cit., n. 2, 50, pl. X, 5 .

46 Palencia: Borobia, op. cit., n. 6, 111, pl. 6, 3 (bronze), pl. 6, 4-5 (bronze); Molina, op. cit., n. 4 , 260, fig. 1, 3-5. Prov. of Soria: Borobia, op. cit., n. 6, 283, pl. 1, 4 and pl. 4, 3 (bronze). 
headache ${ }^{47}$. Although there are few references for their use in surgery. Celsus docs mention that in treating a wound in which the omentum (a fold of the peritoneum) has become gangrenous, it should be cut away with the shears, or in a hernia operation any protruding omentum should thus be removed ${ }^{45}$. Shears, however, were discovered at Merida in conjunction with a surgical saw and a long curved knife which are believed to be equipment for orthopedic surgery, such as amputations ${ }^{49}$.

The fragment of an instrument consisting of a rod and plaque (fig. 8, 1) is similar in size and form to a piece from a private collection in Andalucia which Borobia identifies as a bone lever for raising and realigning depressed bones in fractures, citing one of analogous charac-
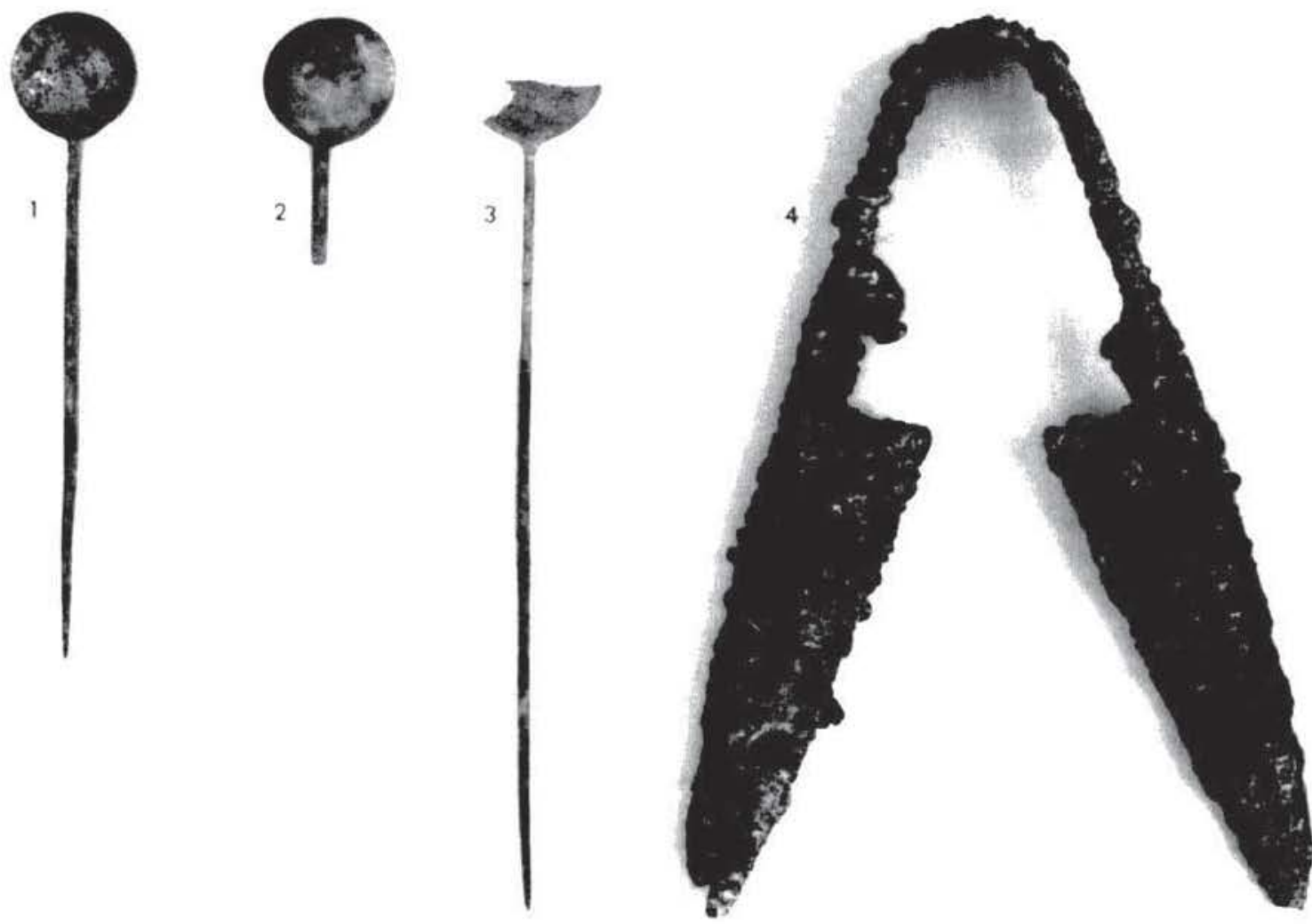

Figura 7.-Spoons and shears from La Cañada Honda (Gandul).

47 Milne, op. cit.. n. 2, 49; Celsus, De Medicina. III, 23, 3: «tunc caput tondere oleoque et aceto perunguere»; IV, 2, 6: «Si vero in his auxilii parum est, tonderi oportet ad cutem».

48 Celsus, De Medicina. VII, 16, 3: «His conditis, omentum quoque considerandum est, ex quo. si quid iam nigri lemortui| est, forfice excidi debet»; VII, 21, 1-C: «Fuerunt etiam qui omentum forfice praeciderent... Neque vero si discusso ventre id prolapsum forfice praeciditur, cum et emortuum sit el aliter tutius avelli non possit, inde huc examplum transferendum est».

49 Floriano, op. cit. n. 2, 425-426; J. R. Zaragoza Rubira, «La Medicina en la España antigua». Cuadernos de Historia de la Medicina. IV. 1965, 178. 
teristics in the Naples Museum ${ }^{50}$. Hippocrates discusses its use, asserting that three sizes are required to be most effective ${ }^{51}$. Galen mentions that a similar instrument is used in dentistry to pry up teeth ${ }^{52}$. Milne suggests that the Naples example may have served the same purpose: perhaps the double lever or chisel with serrated edges (fig. 8,2 ) falls into this category. Instruments of other designs have been identified as bone levers as well ${ }^{53}$.

Both R4390 and R4391 (fig. 8, 3-4) have stylus characteristics. On the other hand, a piece identified as an ear scoop in the Tanzer Collection at Johns Hopkins University is almost identical to R4390 ${ }^{54}$. A stylus in the same collection has the same form as R4391, which is the same type as several instruments classified by Borobia as chisels 55 .

The four slate palettes (fig. 9) for grinding and mixing solid and semi-solid substances for pharmaceutical purposes are similar in size to others that have been found throughout the Empire. All have blunt beveled edges on one face. In some cases the lower edge of the bevel is roughened which suggests that these objects were also used as whetstones for sharpening cutting tools, such as the scalpe ${ }^{56}$. The flat side of the palette apparently served as the work surface as evidenced by the cavity worn in the center of J667 (fig. 9, 3). This also occurs in a palette from a private collection in Madrid ${ }^{57}$. Such palettes were also used by artists in the preparation of pigments. However, they are frequently found in context with the bronze cylindrical cases and rectangular compartmentalized boxes which were used to store and carry drugs and medicaments, some of which still retain evidence of mineral substances ${ }^{58}$. Two cases of this type and fragments of three others are included in the La Cañada Honda group (fig. 10).

50 Borobia, op. cit., n. 6, 73, 201, pl. 53, 1; Milne, op. cit., n. 2, 124, pl. 41, 1.

51 «When fractured bones have come through the integument and cannot be replaced properly, I have here the manner to reduce them. It is necessary to make instruments of iron similar to the levers which stonecutters use, some a little wider and some a little narrower, and there should be three sizes to employ them with better convenience. They would be used in the same way as levers, leaning the lower face of the instrument on the lower fragment. They must be as strong as possible so that they do not bend. If they are well made, and if applied correctly, they are a powerful recourse» (Hippocrates, On fractures, XXXI, 47-63); Borobia, op. cit., n. 6, 73.

${ }_{52}$ Galen, in Hippocrates de fracturis, XVIII, 2, 593; Borobia, op. cit., n. 6, 73.

53 Tabanelli, op. cit., n. 2, pl. 98; Bliquez, op. cit., n. 17, 14-15; Rediscovering Pompeii, exhib. cat., IBM Gallery of Science and Art, New York, 12 July - 15 Sept., 1990, Rome, 1990, 157 and 159, cat. no. 35 .

${ }^{54}$ Bliquez, op. cit., n. 34, 208, fig. 4, 24. Similar examples in the Museo Arqueológico Nacional in Madrid are referred to as small spoons which could also serve as ear probes. See Los Bronces Romanos, exhib. cat., Palacio de Velázquez, Madrid, 1990, 306, no. 272.

55 Bliquez, op. cit., n. 34, 204, 14; Borobia, op. cit., n. 6, 208, pls. 67, 3; 68, 6; 83, 3; 293, pl. 108. 10 , identical in form to the preceding, but referred to as an ear probe.

56 Borobia, op. cit., n. 6, 84. Sáenz de Buruaga y García de Soto, op. cit., n. 2, 75, notes the irregular beveled edges of a palette found at Mérida.

57 Borobia, op. cit., n. 6, 298, pl. 107, 15.

58 Floriano, op. cit., n. 2, 428. Two of four tubes found at Mérida were compartmentalized and still retained residue of mineral substances: copper hydrocarbon, calcium, aluminum, sodium and ferric oxide. The latter, called saffron of Mars or ferrum oxydatum rubrum, was used as a medication by the Romans. 
A long case of the same design served as a receptacle for instruments (fig. 11. 1). Since these have become consolidated and adhere to the case due to oxidation, it is impossible to determine the actual type: nevertheless. some deterioration of the case itself reveals rods, probably of probes or needles. However, some cases, preserved intact elsewhere contain probes. needles and tweezers ${ }^{59}$.

1

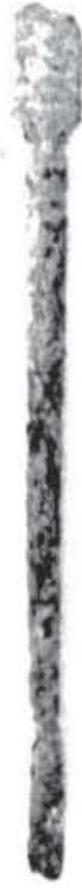

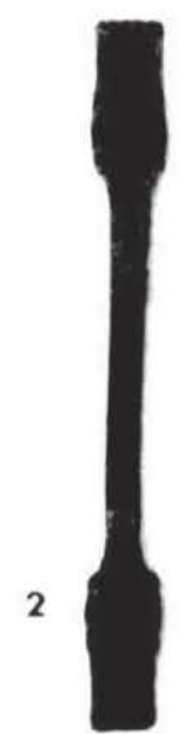

3

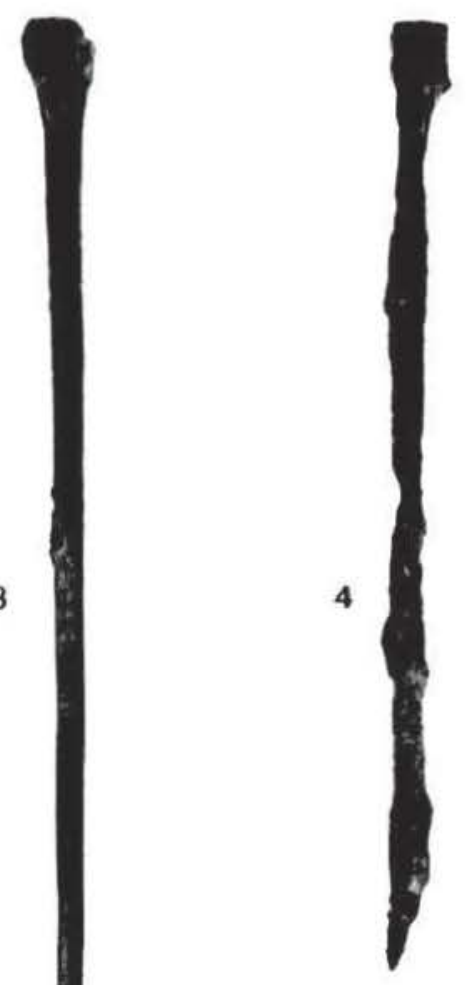

5

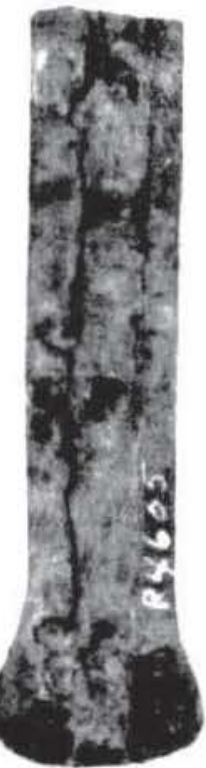

Figura 8.-Possible bone lever, chisel and gouge, a stylus and an unidentified object from La Cañada Honda (Gandul).

59 Tabanelli, op. cit., n. 2, pls. 118-119; Künzl, 106, fig. 83 and 107, fig. 84. 
Although we do not know what instruments are in the more elaborate rectangular case (fig. 11. 2-4), its decoration and unusual design establish it as a luxury item. The repoussé relief on two sides consists of a repeat patern of four groups of animals in combat. The preserved area of the relief begins on the right with a hound and boar group of which only the hound and a part of the boar's head remains. This is followed by a series of elephant/bull, rhinoceros/hull, lion/deer and hound/boar. repeated in the same order. but with only the boar present in the final group on the left.

Already in the Bronze Age representations of such scenes involving lions, bulls, deer, gazelles. sphinxes and griffins were frequent artistic motifs in both Near Eastern and Western art. During the Roman period, as Rome extended its annexations and trade to the east and

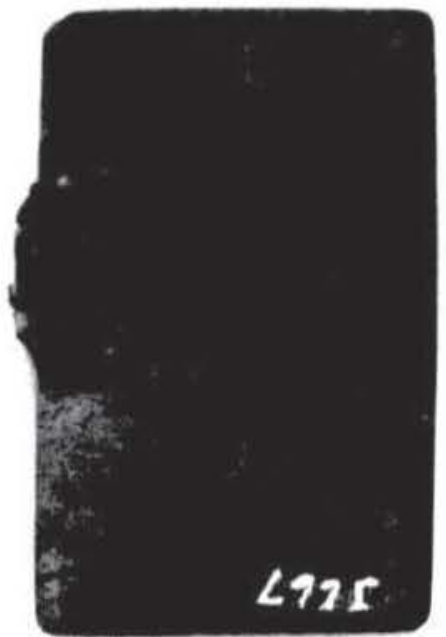

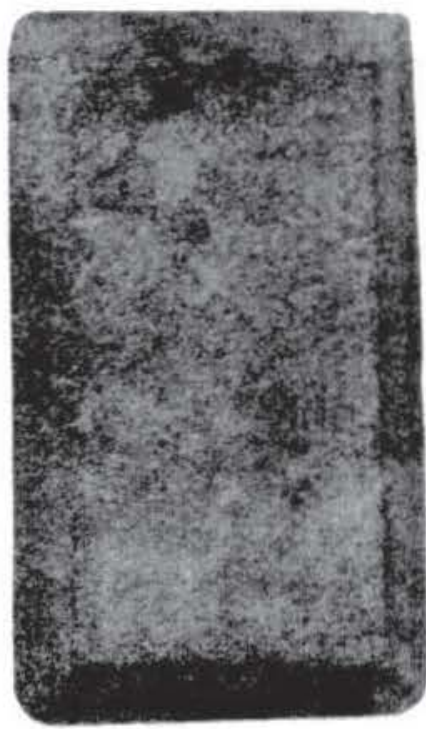

3

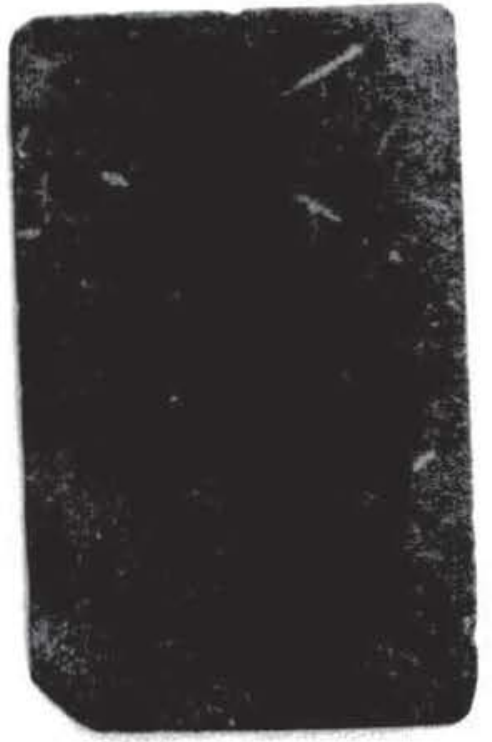

4

2

LA CANADA HONDA (GANDUL)

Figura 9.-Slate palettes from La Cañada Honda (Gandul). 
west, a variety of exotic animals were encountered and transported to Rome for spectacles and games; they quickly gained popularity among the Roman populace and representations of them entered the artist's repertory ${ }^{60}$.
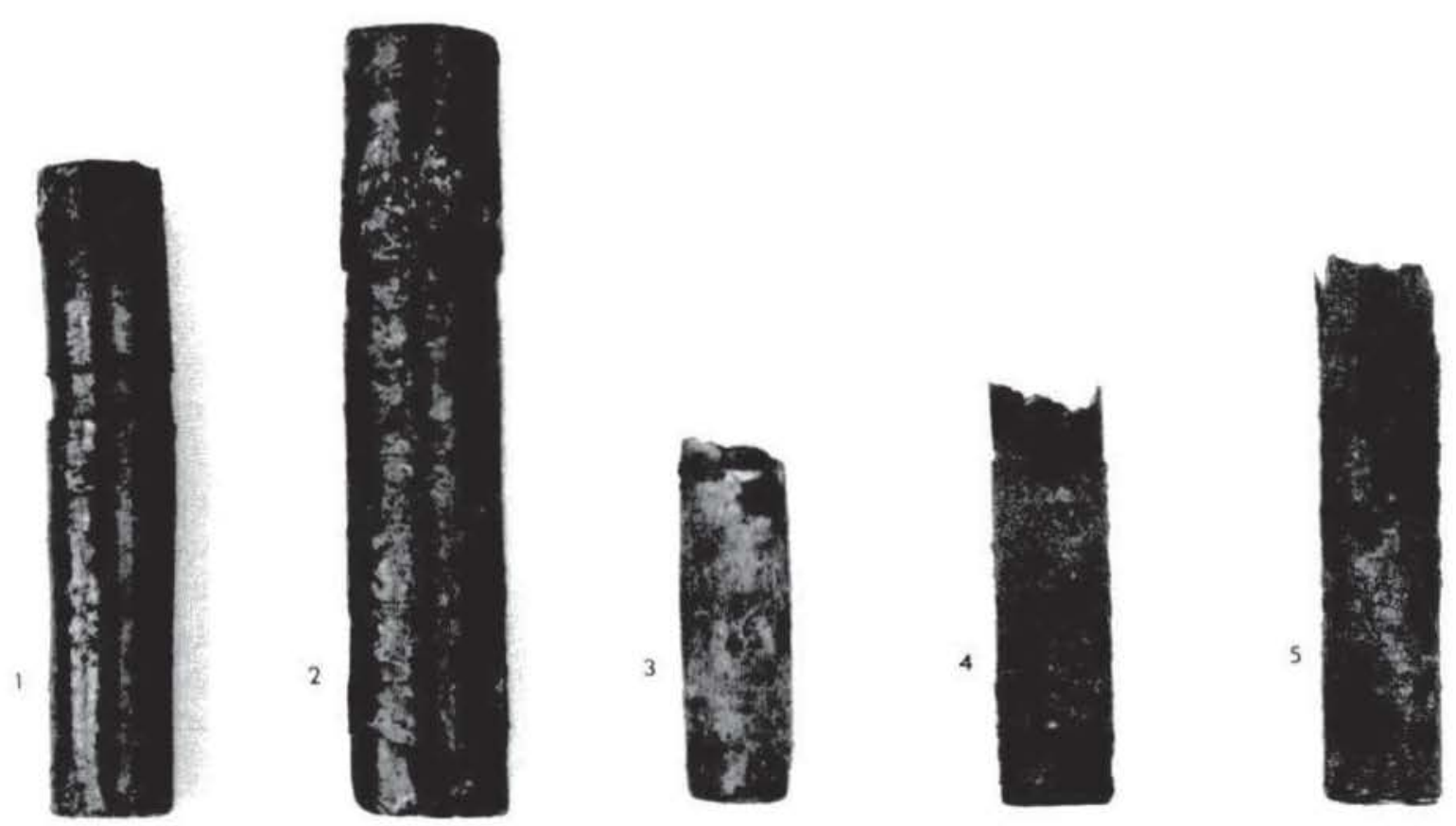

Figura 10. - Medicament or drug cases from La Cañada Honda (Gandul).

As early as the first century B.C. elephants were imported to Rome from India and Africa to engage in animal fights and hunts in the circus and amphitheater. They were first pitted against bulls in Rome in 79 B.C. ${ }^{61}$, and this is reflected in the first group at the right in the relief where the elephant grasps the bull's head with its trunk. Although the relief is worn, microscopic examination reveals the tusks as well as the lozenge patterning of the body, the conventional manner of representing the wrinkled hide of the elephant. In the next group the rhinoceros is depicted with two horns denoting its African origin. An early representation of this beast is found in the mosaic of the Inundation of the Nile in the Santuary of Fortuna at Praeneste, datable to 80 B.C. ${ }^{62}$, but there is no certain evidence for a two-horned rhinoceros in Rome until its appearance on bronze quadrantes issued by Domitian in the first century A.D., and the contemporary poet Martial's description of one tossing a large bear on its two horns as a bull tosses dummies skyward, as well as tossing a huge bull as though it were a dummy ${ }^{63}$. In our relief, only the first moment of confrontation is represented. The next group

60 J. M. C. Toynbee, Animals in Roman Life and Art, lthaca, NY, 1973, 17-18.

of H. H. Scullard. The Elephant in the Greek and Roman World. Ithaca, NY, 1974, 250; Pliny. Naturalis Historia, VIII. 7. 19.

62 Jean Charbonneaux, Roland Martin, and François Villard, Hellenistic Art, New York, 1972, figs. 181-186.

63 Toynbee, op. cit., n. 60, 126; Martial, De spectaculis, 22, 1-6; Epigrams, 1, 9. 
to the left depicting a lion attacking a deer continues the design and style of a very long tradition in both Near Eastern and Western art in which the lion savagely attacks its prey from behind, fiercely biting and forcing it to the ground.

Boar hunting was a popular sport in the ancient world and hounds attacking boars are often prominent elements in sarcophagus reliefs and mosaics depicting such activity - in the latter perhaps capturing live boars for amphitheater display ${ }^{\text {of }}$. But the two animals were sometimes disassociated from these themes and represented as an isolated group, as in a mosaic from Itá-
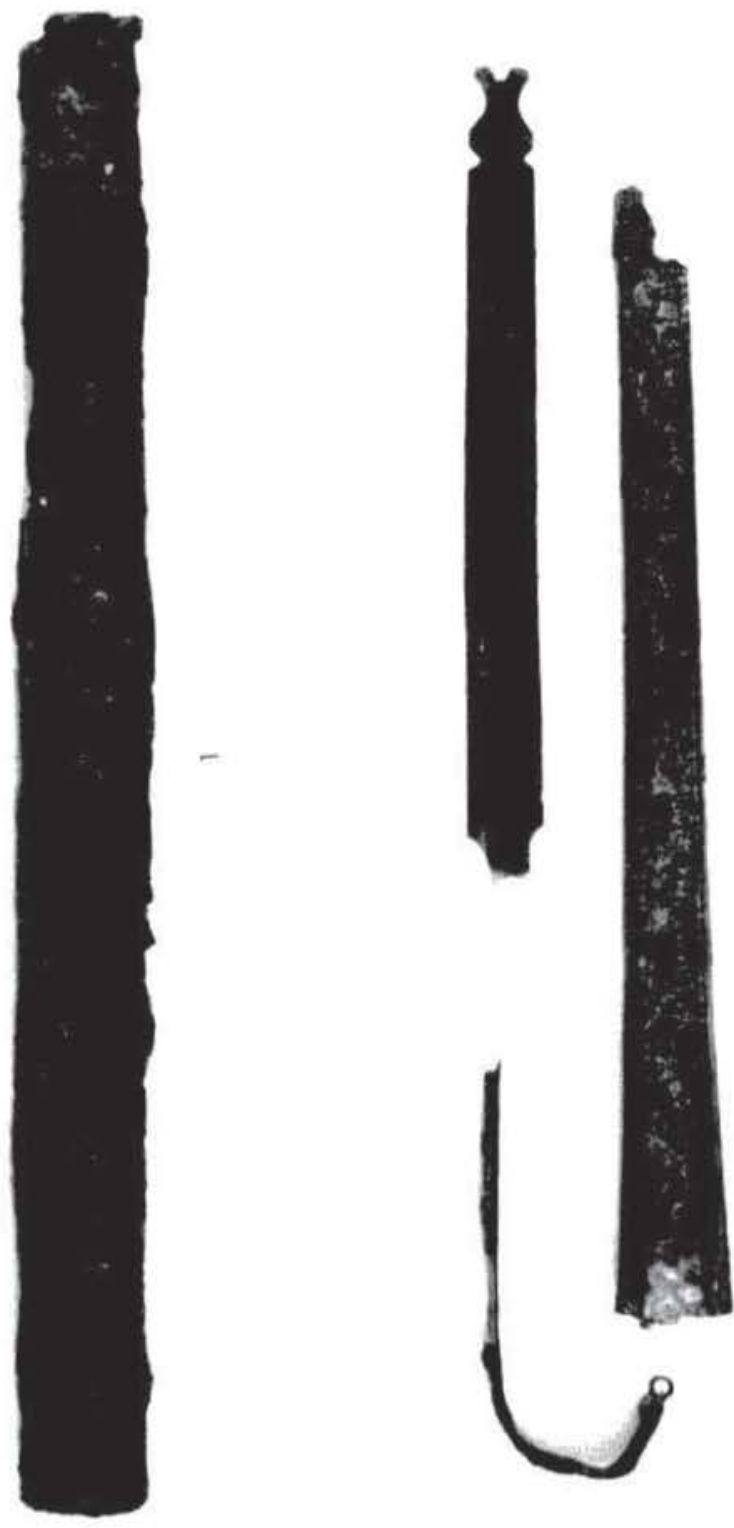

Figura 11.--Instrument cases from La Cañada Honda (Gandul).

64 Toynbee, op, cit., n. 60, 133. 
lica ${ }^{65}$, and in the fourth scene of our relief. The hound is ready to spring forward with its front legs raised while the boar belligerently stands its ground. The dorsal bristles, and corkscrew tail and tusks, though worn, still testify to the fine craftsmanship of the artist.

The overall fine quality of the original modeling of the figures is still evident in the better preserved areas which show the artist's care in rendering anatomical details. This suggests that the artist's source was a pattern book rather than a keen knowledge of animals which would have been infrequently observed. These groups were perhaps selected by the patron commissioning the work who may have witnessed such scenes in the arena ${ }^{66}$. It is conceivable that this person was a gladiatorial doctor such as Galen, who served in this function at the amphitheater at Pergamon early in his career (A.D. 157-161) ${ }^{67}$.

Although there is no evidence of an amphitheater, the amount of glass vessels and ceramics discovered plus the number of incineration graves excavated at La Cañada Honda indicate a thriving community at Mesa de Gandul during the first century A.D. In the tombs previously mentioned, coins from the Vespasianic and Trajanic periods were discovered. The Roman glass from these and other tombs, now in the Society's collections, dates typologically to the first and second centuries A.D. with the majority in the third quarter of the first century A.D. This concurs with the dating of the ceramics from the site which has a proliferation of objects from the middle of the first century ${ }^{68}$. Therefore, a probable date for the surgical instruments would be the second half of the first century and the first half of the second century A.D. with some marginal allowance. Whether they were locally manufactured or imported is uncertain. Because of the similarity of instruments throughout the Empire, some even duplicated, it has been proposed that they were manufactured in Rome. Molina ascribes to this theory, pointing out that workshops specializing in this material are unknown in Spain. She further suggests that the instruments found at Palencia and Belo may have belonged to Roman doctors who had brought their tools with them ${ }^{69}$. Borobia, on the other hand, asserts that while this is probable with respect to the first doctors migrating to Spain, the extensive development of Roman culture in Baetica, including medicine, would almost certainly motivate the fabrication of medical, surgical and pharmaceutical instruments in Spain ${ }^{70}$. While we can draw no firm conclusions in this regard, considering the quantity, quality and types of instruments from $\mathrm{La} \mathrm{Ca}$ ñada Honda, it would appear that there was undoubtedly considerable medical and/or pharmaceutical activity in the area during the first and second century A.D.

65 Blanco Freijeiro, Antonio, Mosaicos romanos de Itálica (I), Madrid, 1978, pl. 39.

66 Handbills or painted placards for the shows giving details of the performances may also have been available to artists (Toynbee, op. cit., n. 60, 31).

67 Scarborough, op. cit., n. 1, 154. Surgical/medical instruments were found in the excavations of the amphitheater at Mérida (Borobia, op. cit., n. 6, 326-7).

68 Amores Carredano, op. cit., n. 7, 128-129.

69 Molina, op. cit., n. 4, 259-260.

70 Borobia, op. cit., n. 6, 237. 


\section{CATALOGUE}

Needles with eyes

1. R4384. Bronze, L. $18.4 \mathrm{~cm}$.; D. $0.2 \mathrm{~cm}$.; Eye - L. $0.5 \mathrm{~cm}$. (fig. 1, 1). Rod, circular in section, upper end flattened with straight edge; elongated eye; blunt point ${ }^{71}$. Condition: Good. Slightly bent $3.7 \mathrm{~cm}$. from the pointed end with some deterioration of the metal at that point.

2. R4385. Bronze. L. $17.2 \mathrm{~cm}$.; D. $0.15 \mathrm{~cm}$.; Eye - L. $0.9 \mathrm{~cm}$. (fig. 1, 2). Rod, circular in section, upper end pointed; elongated eye; medium blunt point. Condition: Good; tip of upper end missing.

3. R4386. Bronze. L. $14.2 \mathrm{~cm}$.; D. $0.15 \mathrm{~cm}$.; Eye - L. $0.9 \mathrm{~cm}$. (fig. 1,3 ). Rod, circular in section, upper end flat and pointed; elongated eye; medium sharp point. Condition: Good.

4. R4387. Bronze. L. $14.3 \mathrm{~cm}$.; D. $0.2 \mathrm{~cm}$.; Eye - L. $0.8 \mathrm{~cm}$. (fig. 1, 4). Similar to the preceding example; fine, sharp point. Condition: Good.

5. R4388. Bronze. L. $11.0 \mathrm{~cm}$; D. $0.15 \mathrm{~cm}$.; Eye - L. $0.6 \mathrm{~cm}$. (fig. 1, 5). Rod, circular in section, upper end flat with straight edge; elongated eye; very fine point, tip missing. Condition: Good ${ }^{72}$.

6. R4392. Bronze. L. $14.3 \mathrm{~cm}$.; D. $0.4 \mathrm{~cm}$.; Eye - L. $0.6 \mathrm{~cm}$. (fig. 1,6 ). Similar to preceding example; fine sharp point. Condition: Good.

7. R4602. Bronze. L. $18.2 \mathrm{~cm}$.; D. $0.48 \mathrm{~cm}$; Eye $-0.35 \mathrm{~cm}$. (fig. 1, 7). Similar to preceding example, medium point. Condition: Fair, broken at top through eye.

\section{Needles without eyes}

8. R4604. Bronze. L. $18.2 \mathrm{~cm}$.; W. $0.4 \mathrm{~cm}$. at top (fig. 2, 1). Rect. sect. - L. $1.6 \mathrm{~cm}$.; W. $0.65 \mathrm{~cm}$.

Flattened rectangular section with two perforations joined to a trapezoidal rod which tapers to a fine triangular point. Edges of rectangular section slightly raised on one face; upper perforation slightly larger than lower and both show mark of rivet or nail on the flat face by which a handle was probably attached. Borobia illustrates an almost identical piece, but does not discuss it ${ }^{73}$.

9. R4395. Bronze. L. 8.74 cm.; D. $0.3 \mathrm{~cm}$. (fig. 2, 2). Short rod, circular in section; fine sharp point. Condition: Good.

10. R4260. Bronze. L. 10.7 cm.; D. 0.17 cm.; grip - L. 2.5 cm., W. $1.1 \mathrm{~cm}$. (fig. 2, 3). Double needle, circular in section, central triangular grip; points missing. Condition: Good.

11. R4606. Bronze. L. $5.4 \mathrm{~cm}$.; W. $0.4 \mathrm{~cm}$. (fig. 2, 4). Short trapezoidal rod tapers to a triangular fine, sharp point; slight rectangular projection at top. Condition: Surface slightly worn.

\footnotetext{
71 Borobia, op. cit., n. 6, pl. 111, 14 shows the same type.

72 Borobia, op. cit., n. 6, pl. 11I, 10, shows a very similar example.

73 Borobia, op. cit., n. 6, pl. 111, 11.
} 
12. R4607. Bronze. L. $8.65 \mathrm{~cm}$.; W. $0.35 \mathrm{~cm}$. (fig. 2,5 ).

Rod, trapezoidal in section; fine triangular point; flat top.

Condition: Good.

13. R4644. Bronze. L. $8.1 \mathrm{~cm} . ;$ W. $0.51 \mathrm{~cm}$. (fig. 2,6 ).

Rod, trapezoidal in section; flat top; medium fine point, slightly bent.

Condition: Good.

\section{Needle handle}

14. R4366. Bronze. L. $8.6 \mathrm{~cm}$.; spatula - L. $4.5 \mathrm{~cm}$., W. $0.7 \mathrm{~cm}$.; handle - L. $4.2 \mathrm{~cm}$., W. $0.6 \mathrm{~cm}$. (fig. $2,7)$.

Long, narrow leaf-shaped spatula; hexagonal handle ornamented with a damascened spiral; round perforation in base still retains the end of the original needle.

Condition: Good.

\section{Scalpel handles}

15. R4364. Bronze and Silver. L. $7.7 \mathrm{~cm}$.; spatula - L. $3.4 \mathrm{~cm}$., W. 0.82 ; handle - L. $4.3 \mathrm{~cm}$., D. 0.65 cm. (fig. 3, 1).

Leaf-shaped spatula joined to a pyriform handle, ornamented with a damascened spiral and molded rings, which is attached to a rectangular handle having a cylindrical roll on the slotted end.

Condition: Good.

16. R4365. Bronze and iron. L. $9.6 \mathrm{~cm}$.; spatula - L. $5.6 \mathrm{~cm}$., W. $1.1 \mathrm{~cm}$.; handle - L. $3.0 \mathrm{~cm}$. , W. 1.0 cm.; blade, L. $1.0 \mathrm{~cm}$. (fig. 3, 2).

Wide, thick leaf-shaped spatula joined to a plain rectangular handle which retains portion of iron blade in slotted end which is finished with a cylindrical roll.

Condition: Good.

17. R4643. Bronze. L. $7.6 \mathrm{~cm}$.; spatula - L. $3.8 \mathrm{~cm}$., W. $0.6 \mathrm{~cm}$.; handle - L. $3.8 \mathrm{~cm}$., W. $0.4 \mathrm{~cm}$. (fig. $3,3)$.

Narrow leaf-shaped spatula; plain octagonal handle with groove in the base.

Condition: Good.

18. R4645. Bronze. L. 7.5 cm.; spatula - L. $3.8 \mathrm{~cm}$., W. $0.8 \mathrm{~cm}$.; handle - L. $3.7 \mathrm{~cm}$., W. $0.51 \mathrm{~cm}$.; groove $-0.49 \mathrm{~cm}$. (fig. 3,4 ).

Long, narrow leaf-shaped spatula; octagonal handle with deep groove in base and groove on both faces $1.0 \mathrm{~mm}$. from the end; remnant of iron blade still in groove.

Condition: Good.

19. R4156. Bronze. L. $7.6 \mathrm{~cm}$.; spatula - L. $4.0 \mathrm{~cm}$., W. $0.8 \mathrm{~cm}$., handle - L. $3.6 \mathrm{~cm}$., W. $0.4 \mathrm{~cm}$. (fig. $3,5)$.

Fine narrow leaf-shaped spatula; octagonal handle with groove in base.

Condition: Good.

\section{Probes (cyathiscomele)}

20. R4155. Bronze. L. $12.9 \mathrm{~cm}$.; D. probe $-0.5 \mathrm{~cm}$., rod $-0.3 \mathrm{~cm}$.; W. spoon $-0.9 \mathrm{~cm}$. (fig. 4,1 ).

Rod, circular in section, with olivary probe on one extremity and leaf-shaped spoon on other; decorated with a molded pyriform with incised diamond design below spoon followed by two rings, globe and ring.

Condition: Good. 
21. R4405. Bronze. L. $14.2 \mathrm{~cm}$.; D. probe $-0.4 \mathrm{~cm}$., rod, $0.2 \mathrm{~cm}$.; W. spoon $-0.6 \mathrm{~cm}$. (fig. 4,2 ). Similar to preceding example; molded ring and globe below the spoon.

Condition: Good.

22. R4407. Bronze. L. $13.9 \mathrm{~cm}$.; D. probe $-0.24 \mathrm{~cm}$., rod $-0.33 \mathrm{~cm}$.; W. spoon, $0.55 \mathrm{~cm}$. (fig. 4,3 ). Similar to preceding examples molded ring and globe at the base of the spoon. Condition: Good.

23. R4408. Bronze. L. $16.8 \mathrm{~cm}$.; D. probe $-0.5 \mathrm{~cm}$., rod $-0.3 \mathrm{~cm}$.; W. spoon $-0.69 \mathrm{~cm}$. (fig. 4,4 ). Similar to preceding examples; alternating pairs of molded rings and globes at base of spoon. Condition: Broken at base of spoon.

24. R4409. Bronze. L. $14.7 \mathrm{~cm}$.; D. probe $-0.6 \mathrm{~cm}$.; rod, $0.4 \mathrm{~cm}$.; W. spoon $-0.7 \mathrm{~cm}$. (fig. 4,5 ). Similar to preceding examples; five molded rings at base of spoon. Condition: Spoon broken and separated from rod; restored.

25. R4393. Bronze. L. $14 \mathrm{~cm}$.; D. probe $-0.4 \mathrm{~cm}$., rod $0.16 \mathrm{~cm}$. (fig. 4,6 ). Similar to preceding examples molded globe and ring at base of spoon. Condition: Good.

\section{Probe Tragments}

26. R4410. Bronze. L. $18 \mathrm{~cm}$.; D. probe $-0.4 \mathrm{~cm}$., rod, 0.2 ; W. spoon $-0.7 \mathrm{~cm}$. (fig. 4,7 ). Similar to preceding examples; five molded rings at base of spoon. Condition: Fair, broken in the middle of the rod; end of spoon missing.

27. R4411. Bronze. L. $7.8 \mathrm{~cm}$.; D. rod $-0.2 \mathrm{~cm}$.; W. spoon $-0.52 \mathrm{~cm}$. (fig. 4,8 ). Fragment of probe preserving spoon and half of rod. Condition: Fair.

28. R4412. Bronze. L. $10.4 \mathrm{~cm}$. D. probe $-0.31 \mathrm{~cm}$., rod $-0.2 \mathrm{~cm}$.; (fig. 4,9 ). Similar to preceding examples; end of the spoon missing; three molded globes at base of spoon. Condition: Fair.

29. R4394. Bronze. L. $11.85 \mathrm{~cm}$.; D. probe $-0.48 \mathrm{~cm}$., rod $-0.2 \mathrm{~cm}$. (fig. 4,10 ). Similar to preceding examples; four molded rings at base of spoon. Condition: Fair, spoon missing.

30. R4396. Bronze. L. $8.9 \mathrm{~cm}$.; D. rod $-0.35 \mathrm{~cm}$. (fig. 4,11 ). Similar to preceding examples; rod only preserved. Condition: Fair.

31. R4406. Bronze. L. $5.15 \mathrm{~cm}$; D. probe $-0.4 \mathrm{~cm}$., rod $-0.2 \mathrm{~cm}$. (fig. 4,12 ). Fragment of probe preserving only half of rod and olivary end. Condition: Poor.

32. R4413. Bronze. L. $10.2 \mathrm{~cm}$.; D. probe $-0.41 \mathrm{~cm}$., rod $-0.21 \mathrm{~cm}$. (fig. 4,13 ). Similar to preceding examples; spoon missing. Condition: Fair.

\section{Probe (spathomele)}

33. R4634. Bronze. L. $12 \mathrm{~cm}$.; W. spatula $-0.8 \mathrm{~cm}$., rod - $0.2 \mathrm{~cm}$., probe - 0.4 (fig. 4,14 ).

Rod, circular in section, with olivary probe on one extremity and leaf-shaped spoon on other; decorated with three pairs of molded rings alternating with two globes below the spoon and a pair of rings $3.4 \mathrm{~cm}$. from the opposite end.

Condition: Good. 
Ear Probes (auriscalpium or oricularium specillum)

34. R4336. Bronze. L. $16.1 \mathrm{~cm}$.; D. probe $-0.4 \mathrm{~cm}$., rod $-0.3 \mathrm{~cm}$., scoop - 0.51 (fig. 5,1 ).

Rod, circular in section. with a small scoop set at an angle to the rod on one end; olivary probe on opposite extremity; molded globe $3.0 \mathrm{~cm}$. from scoop. Condition: Good.

35. R4337. Bronze. L. $12.1 \mathrm{~cm}$.; D. rod $-0.2 \mathrm{~cm}$., scoop - $0.6 \mathrm{~cm}$. (fig. 5,2 ). Similar to preceding example with customary sharp point on one extremity. Condition: Good.

36. R4338. Bronze. L. $11.1 \mathrm{~cm}$.; D. rod - 0.25 , scoop - 0.5 (fig. 5,3 ). Similar to preceding example.

Condition: Good.

37. R4339. Bronze. L. $11.6 \mathrm{~cm}$.; D. rod -0.2 , scoop - $0.5 \mathrm{~cm}$. (fig. 5,4 ). Similar to preceding example. Condition: Good.

38. R4340. Bronze. L. $11.5 \mathrm{~cm}$.; D. rod $-0.2 \mathrm{~cm}$., scoop $-0.55 \mathrm{~cm}$. (fig. 5,5 ). Similar to preceding example. Condition: Good.

39. R4341. Bronze. L. $10 \mathrm{~cm}$.; W. scoop - $0.4 \mathrm{~cm}$.; D. rod $-0.17 \mathrm{~cm}$. (fig. 5,6 ). Similar to preceding example; very small scoop; pointed end missing. Condition: Fair.

40. R4342. Bronze. L. $9.4 \mathrm{~cm}$.; D. rod - $0.17 \mathrm{~cm}$. (fig. 5,7 ). Similar to preceding example; small portion of scoop remains; fine, sharp point. Condition: Good.

41. R4342a. Bone. L. $7.5 \mathrm{~cm}$.; D. rod - 0.45 , scoop - $0.7 \mathrm{~cm}$. (fig. 5,9 ). Rod, cylindrical in section; round scoop; opposite extremity missing. Condition: Poor.

42. R4397. Bronze. L. $2.0 \mathrm{~cm}$.; D. rod $-0.2 \mathrm{~cm}$., scoop - $0.5 \mathrm{~cm}$. (fig. 5,8 ). Fragment of rod, cylindrical in section; round scoop; opposite extremity missing. Condition: Rod broken and restored.

Tweezers

43. R4182. Bronze. L. $10.7 \mathrm{~cm}$; W. $1.1 \mathrm{~cm}$. (fig. 6,1 ). Single strip of metal bent on itself forming a ring at the apex; ends turned inward at a sharp angle forming jaws. Condition: Good.

44. R4183. Bronze. L. $11 \mathrm{~cm}$.; W $0.6 \mathrm{~cm}$. (fig. 6,2 ). Similar to preceding example. Condition: Fair, arms spread outward.

45. R4187. Bronze. L, $11.6 \mathrm{~cm}$.; W. $0.6 \mathrm{~cm}$. (fig. 6, 3). Similar to preceding example. Condition: Fair, one leg bent outward.

46. R4184. Bronze. L. $9.5 \mathrm{~cm}$.; W. $0.65 \mathrm{~cm}$. (fig. 6, 4). Similar to preceding example. Condition: Good.

47. R4185. Bronze. L. $10.2 \mathrm{~cm}$; W. $0.5 \mathrm{~cm}$. (fig. 6, 5). Similar to preceding example. Condition: Surface corroded.

48. R4263. Bronze. L. $9.05 \mathrm{~cm}$. W. $0.4 \mathrm{~cm}$. (fig. 6, 6). 
Similar to preceding example.

Condition: Good.

49. R4261. Bronze. L. $7.2 \mathrm{~cm}$.; W. 1.1 (fig. 6, 7).

Similar to preceding examples; pierced at top.

Condition: Fair.

50. R4186. Bronze. L. $10.8 \mathrm{~cm}$.; W. $0.6 \mathrm{~cm}$. (fig. 6,8 ).

Similar to preceding example; sliding catch.

Condition: Fair, surface corroded.

51. R4188. Bronze, L. $8.3 \mathrm{~cm}$.; W. $0.35 \mathrm{~cm}$. (fig. 6,9 ).

Similar to preceding example.

Condition: Good.

\section{Spoons}

52. R4132. Bronze. L. $11 \mathrm{~cm}$.; D. of bowl $-2.1 \mathrm{~cm}$. (fig. 7, 1).

Rod, cylindrical in section, pointed on one extremity; round spoon on opposite end.

Condition: Good.

53. R4133. Bronze. L. $4.7 \mathrm{~cm}$.; D. of bowl $-2.3 \mathrm{~cm}$. (fig. 7, 2).

Fragment of spoon preserving small portion of handle and bowl.

Condition: Fair; small hole in center of bowl.

54. R4640. Bronze. L. $14.2 \mathrm{~cm}$.; approx. D. of bowl - $2 \mathrm{~cm}$. (fig. 7, 3).

Similar to R4132; fragmentary bowl.

Condition: Poor.

\section{Miscellaneous}

55. Shears. R4389. Iron. L. $15 \mathrm{~cm}$.; W. $10.5 \mathrm{~cm}$.; Blade - L. $2.5 \mathrm{~cm}$;; W. $2.5 \mathrm{~cm}$. at top (fig. 7, 4).

Two triangular blades with a cutting edge on inner side joined by a flat $U$-shaped strip; metal still retains some resiliency ${ }^{74}$.

Condition: Very corroded.

56. Bone lever or chisel. R4641. Bronze. L. $9.7 \mathrm{~cm}$.; plaque - L. $1.5 \mathrm{~cm}$.; W. $0.7 \mathrm{~cm}$; rod - D. $0.4 \mathrm{~cm}$. (fig. 8, 1).

Rod, circular in section, molded ring and globe on one end which is attached to a flat rectangular plaque; grooved on end near handle on both faces; opposite extremity missing.

Condition: Fair.

57. Chisel. R4603. Bronze. L. $7.9 \mathrm{~cm}$., plaque $-1.8 \mathrm{~cm}$.; W. rod $-0.4 \mathrm{~cm}$., plaque $-0.83 \mathrm{~cm}$. (fig. 8,2 ). Double instrument consisting of a flat rod attached to a rectangular plaque on each end, both with serrated edges.

Condition: Good.

58. Stylus. R4390. Bronze. L. 17.5 cm.; rect. sect. - L. $0.8 \mathrm{~cm}$., W. $0.8 \mathrm{~cm}$.; rod - D. $0.34 \mathrm{~cm}$. (fig. 8 , $3)$.

Rod, cylindrical in section, having a flat rectangular section with sharp edge on one extremity and a sharp point on the other.

Condition: Good; small piece missing on upper right.

${ }^{74}$ Two scissors similar in size and form from the province of Soria are considered to be medical by Borobia, op. cit., n. 6, 286, pl. 77, iron, and 288, bronze, pl. 76, and Mérida, 246, pl. 90, 7, iron. 
59. Gouge or stylus. R4391. Iron. L. $9.3 \mathrm{~cm}$.; rod - D. $0.3 \mathrm{~cm}$.; plaque - L. $0.8 \mathrm{~cm}$.: W. $0.8 \mathrm{~cm}$. (fig. $8,4)$. Cylindrical rod pointed on one end and a rectangular plaque of triangular section with a cutting edge on opposite extremity. Condition: Poor: rod badly corroded.

60. Palette. J667. Slate. L. $7.4 \mathrm{~cm}$.; W. $4.7 \mathrm{~cm} . ;$

Small rectangular palette for preparation of solid and semisolid medications; beveled edge of lower surface; finger ring set with paste-glass setting attached to one edge by some adhesive substance. obviously in the tomb.

Condition: Cavity worn in center on flat side 75 .

61. Palette. J668. Slate. L. $11.9 \mathrm{~cm}$.; W. $6.6 \mathrm{~cm}$.; D. $1.7 \mathrm{~cm}$.; beveled edge $0.7 \mathrm{~cm}$. (fig. 9, 2).

Similar to preceding example without cavity.

Condition: Good.

62. Palette. J669. Slate. L. $8.6 \mathrm{~cm}$.; W. $5.4 \mathrm{~cm}$.; D. $0.65 \mathrm{~cm}$.; beveled edge $1.0 \mathrm{~cm}$. (fig. 9.3 ). Similar to preceding example.

Condition: Good.

63. Palette. J670. Slate. L. $8.4 \mathrm{~cm}$.; W. $4.9 \mathrm{~cm}$.; D. $0.7 \mathrm{~cm}$. (fig. 9,4 ).

Similar to preceding example.

Condition: Good.

\section{Medicament or drug cases}

64. R4404. Bronze. Bottom - L. $9.7 \mathrm{~cm}$; cover - L. $3.3 \mathrm{~cm}$.; D. $1.8 \mathrm{~cm}$. (fig. 10, 1).

Hollow cylindrical case consisting of two parts; top piece fits over a tube slightly smaller in diameter which was soldered into upper part of the bottom piece; each piece closed on one end with a circular disk soldered to the tube; ornamented with concentric circles.

Condition: Fair.

65. R4403. Bronze. L. $11.1 \mathrm{~cm}$; D. $2.2 \mathrm{~cm}$. (fig. 10, 2).

Similar to preceding example, but the two parts now fused together due to oxidation; bottom disk and small portion of tube missing.

Condition: Fair.

66. R4089. Bronze. L. 7.7 cm.; D. 1.7 cm. (fig. 10, 3).

Portion of bottom of case.

Condition: Poor.

67. R4090. Bronze. L. $6.1 \mathrm{~cm}$.; D. $1.7 \mathrm{~cm}$. at bottom and $1.6 \mathrm{~cm}$. at top (fig. 10,4).

Bottom of case with a portion of the inserted tube missing; circular disk on end ornamented with a raised circle.

Condition: Fair.

68. R4091. Bronze. L. $7.8 \mathrm{~cm}$.; D. $1.7 \mathrm{~cm}$. (fig. 10, 5).

Similar to preceding example; circular disk partly separated from tube.

Condition: Poor.

\section{Instrument Cases}

69. R4402. Bronze. L. $19.1 \mathrm{~cm}$.; D. $1.7 \mathrm{~cm}$. (fig. 11, 1).

Cylindrical case of two sections; similar in construction to R4404, but fused together and to instruments due to oxidation.

Condition: Poor.

75 See Borobia, op. cit., no. 6, 298-299, pl. 107, 15 for a similar example. 
70. R4.368-70. Bronze, R4.370 - L. $14.6 \mathrm{~cm}$. W. $1.0 \mathrm{~cm}$. (fig. 11,2 ). R4.368 - L. $5.4 \mathrm{~cm}$. . W. $1.14 \mathrm{~cm}$. ; R4.369 - L. $10.7 \mathrm{~cm} . ;$ W. $1.0 \mathrm{~cm}$.

Rectangular instrument case, preserved in three pieces, ornamented with repoussé animal combat fricze. R437() preserves a frieze consisting of a repeat design of four pairs of animals in combat: an elephant attacking a bull, a rhinoceros confronting a bull, a dog confronting a boar, and a lion attacking a deer. Several badly corroded instruments still adhere to the interior. Since this piece retains two plain sides and R4368 and R4369, although in poor condition, apparently had the same ornamentation and appear to belong together, they probably formed the fourth side or cover of the case which could be lifted via the hinge on the curved end of R4368 to open the case. The fish-tail ornament at the lower end of R4369 could have served as part of the latch to secure the cover to the case.

Condition: R4370 - fair; R4368 and R4369 - poor.

71. Unidentified. R4605. Bronze. L. $8.4 \mathrm{~cm}$.; W. $2.35 \mathrm{~cm}$. and $1.65 \mathrm{~cm}$. (fig. 8,5 ).

Flat strip of metal with the sides folded inward along the sides $1.0 \mathrm{~cm}$. at the top and $0.5 \mathrm{~cm}$ along the sides $^{76}$.

Condition: Fair.

${ }^{76}$ Borobia illustrates a similar piece (op. cit., n. 6, pl. 63, 8), but does not discuss it. The sides appear to be turned up at one end. 